\title{
Performance Evaluation of Waste Heat Recovery in a Charcoal Stove using a Thermo- Electric Module
}

\author{
Nnamdi Judges Ajah ${ }^{*}$
}

1 Nigerian Defence Academy, NIGERIA

*Corresponding Author: ajudges@gmail.com

Citation: Ajah, N. J. (2018). Performance Evaluation of Waste Heat Recovery in a Charcoal Stove using a Thermo-Electric Module. European Journal of Sustainable Development Research, 2(2), 25. https://doi.org/10.20897/ejosdr/85187

Published: March 13, 2018

\begin{abstract}
Charcoal stoves have widespread use among the poorer households and outdoor food vendors in Nigeria. In order to improve the efficiency of charcoal stoves, various researches have tried integrating a thermoelectric module in the charcoal stove. The researches, however did not exploit the performance of the thermoelectric modules at different ambient temperatures. To evaluate the performance of thermoelectric integrated charcoal stoves in the sub-Saharan Africa, a self-powered, forced air induced thermoelectric charcoal stove experiment was carried out at five different ambient temperatures of $36^{\circ} \mathrm{C}$, $33^{\circ} \mathrm{C}, 32^{\circ} \mathrm{C}, 30^{\circ} \mathrm{C}$ and $29^{\circ} \mathrm{C}$ and an average fuel hotbed temperature of $1023.75^{\circ} \mathrm{C}$. The thermoelectric charcoal stove generated a maximum voltage of $5.25 \mathrm{~V}$ at an ambient temperature of $29^{\circ} \mathrm{C}$. The least maximum voltage was generated at the highest ambient temperature of $36^{\circ} \mathrm{C}$. It was observed that the maximum voltage increased with decreasing ambient temperature, this could be attributed to the ambient air being used to cool the thermoelectric generator. Therefore, it could be said that the performance of a forced draft thermoelectric charcoal stove increases with decrease in ambient temperature.
\end{abstract}

Keywords: thermoelectric, charcoal, stove, sub-Saharan Africa

\section{INTRODUCTION}

Charcoal is widely accepted as fuel for cooking especially in Sub-Sahara Africa and other developing nations. Given that large numbers of people still use inefficient charcoal stoves (E+Carbon, 2009), it is necessary to design low-cost efficient charcoal burners.

For cooking stoves, the amount of the heat content of the charcoal transferred to the load/cooking vessel determines the efficiency. Equation 1 gives the formula for calculating the efficiency of the stove;

$$
\eta_{\mathrm{s}}=\frac{\text { Heat transferred to the load }}{\text { Heat content of fuel }}
$$

Currently, a great deal of efforts have been put into making low-cost efficient charcoal burners. According to Toyola Energy Limited, their charcoal burner ToyolaCoalpot is 33\% more fuel-efficient than traditional charcoal burners (E+Carbon, 2009). This is achieved by the introduction of a ceramic liner inside the combustion zone, which increases combustion efficiency and retains heat. The ceramic liner is said to have a potential to improve fuel efficiency by up to 50\% (E+Carbon, 2009). Also, to achieve improved energy efficiency with low-cost, a prototype charcoal stove has been built using principles of combustion and heat transfer to improve stove efficiency (Milind, 2009). 
A unique method of increasing efficiency of the charcoal burner is by recovering the waste heat; this can be done through the use of a thermoelectric module. The concept of thermoelectric generator (TEG) integrated stove research was first done by J.C Bass and Killander in 1996 (Killander and Bass, 1996). The main objective was to make the stove very affordable and efficient for rural people and others devoid of electricity.

Nuwayhid et al studied the possibility of using a proportion of the heat from $20-50 \mathrm{~kW}$ wood stove, to provide a continuous 10-100W electric power supply (Nuwayhid et al., 2003). In a first prototype, they used a cheap Peltier module for their TE generator. The maximum power for a module was found to be very low (1W) mostly because of the limited temperature difference due to the maximum temperature supported by the module. It is also because of the geometry, which was optimized for cooling and not generating power. In addition, natural air was used to cool the cold-side of the module. In a subsequent prototype their TE generator used 1, 2 or 3 commercially available low-cost power generator modules (Nuwayhid and Hamade, 2005). The cold side of the TE modules was naturally cooled with the surrounding air. They got a maximum power of $4.2 \mathrm{~W}$ for one thermoelectric module and they showed that the output per module decreased when the number of thermoelectric modules in the thermoelectric generator increased (Nuwayhid and Hamade, 2005). This is as a result of the decrease in temperature difference between opposite sides of the thermoelectric module.

Nuwayhid in one of the tests used heat pipes for the heat sink (Nuwayhid and Hamade, 2005). The maximum power obtained was about 3.4W. Lertsatitthanakorn replicated the same experiment with a commercial TE module made of bismuth telluride based materials to the stove's side wall, thereby creating a TE generator system that utilizes a proportion of the stove's waste heat, while also using heat pipes at the cold side to maintain a temperature difference across the module (Lertsatitthanakorn, 2007). The results show that the system generates a power output of approximately $2.4 \mathrm{~W}$ when the temperature difference is $150^{\circ} \mathrm{C}$. His economic analysis indicated that the payback period was very short.

At the ETHOS 2005 congress, Mastbergen and Wilson presented a prototype of a thermoelectric generator with a forced-air cooling for the cold side with a 1W fan (Mastbergen et al., 2005), 4W of net power was produced by the thermoelectric generator and it was able to power an array of high intensity LEDs.

Daniel Champier et al were able to produce $9.5 \mathrm{~W}$ of electric power in a forced draft stove using bismuth telluride (Champier et al., 2011). Ice was used to maintain a temperature of under $100^{\circ} \mathrm{C}$ at the cold side and therefore a temperature difference across the module. They were able to show that the performance of the thermoelectric generator was influenced by the heat transfer through the modules and especially by the thermal contact resistances. The aluminum surface of the heat sinks used was reduced to a flatness of 25 micrometers (standard deviation of height). Mastbergen highlighted the role played by thermal contact resistances in thermoelectric generator performance (Mastbergen et al., 2005). According to him, the thermal resistances at the interfaces between the module and the heat sinks are also important to keep to a minimum, and recommended very flat surfaces of within 0.001 ”. Daniel Champier et al suggested that a resistance of $500 \mathrm{kPa}$ was sufficient to minimize the contact resistance for the thermoelectric (Champier et al., 2011). In another experiment, Daniel Champier made use of four (4) TE modules in series and tried two different cooling systems (Champier et al., 2011):

1. A heat fins exchanger being placed on the cold side with a $10 \mathrm{~W}$ air fan; and

2. A water tank directly put on the cold side of the TE module.

The amount of water contained in the tank applied a pressure of $10 \mathrm{kPa}$. A weight placed on rods above the fan applied the same pressure on the cell. By comparing the evolution of the temperature of the two cooling devices, it was learnt that for equivalent temperatures on the hot side, different temperatures on the cold side were reached. The cold-side temperature reached $117^{\circ} \mathrm{C}$ when the air fan was used, whereas, it was only $65^{\circ} \mathrm{C}$ with the use of ice; therefore, cooling with the air fan was not as efficient as with ice. In the experiment, a total power of about $7 \mathrm{~W}$ was produced with a temperature difference of $160^{\circ} \mathrm{C}$ between the two sides of the generator. Measuring each cell independently to ascertain their individual performance, it was found that the maximum power reached by each module varied between $1.7 \mathrm{~W}$ and $2.3 \mathrm{~W}$ for a temperature difference between the sides of $160^{\circ} \mathrm{C}$. It was also verified that the efficiency of a TE module is proportional to $\Delta \mathrm{T}$ which is reasonable, as the output power is proportional to $\Delta \mathrm{T}^{2}$ and heat flux to $\Delta \mathrm{T}$. For a temperature difference of $60^{\circ} \mathrm{C}$, the efficiency of a thermoelectric module is about $0.6 \%$ and the heat flow through the module is around $100 \mathrm{~W}$. However, a thermoelectric module efficiency of about $2 \%$ is obtained when computer simulation is done with a temperature difference of $200^{\circ} \mathrm{C}$ (Champier et al., 2011).

A commercially available biomass stove in the U.S., BioLite, uses a thermoelectric generator to create clean, efficient cooking with a forced-air draft fan (BioLite, 2015). Additionally, it has a $5 \mathrm{~W}$ outlet powered by the TE generator that can be used to charge/power various electronic devices.

Rinalde et al were able to generate a maximum electrical power of $10 \mathrm{~W}$ through the use of a heat pump, which certainly decreased the available output power (Rinalde et al., 2010). Their laboratory prototype used an electric 
heater for the heat source and forced water cooling system to maintain a temperature difference across the thermoelectric module.

O'Shaughnessy et al used a single Seebeck optimized thermoelectric module with forced air cooling and heat pipes applied at the cold side of module to convert a small portion of heat from a stove to electricity (O'Shaughnessy et al., 2013). The electricity produced was used to charge a single 3.3V lithium-ion phosphate battery and drive a low power fan, as well as some other auxiliary features. The airflow produced by the fan was used in conjunction with a commercially available heat pipe heat sink to maintain an adequate temperature difference across the thermoelectric module. From experiments in the laboratory, a maximum TEG power output of $5.9 \mathrm{~W}$ has been obtained. On average, $3 \mathrm{Wh}$ of energy was stored in a battery during a typical $1 \mathrm{hr}$ long burn. Three $1 \mathrm{hr}$ long burns produced sufficient energy to fully charge the battery.

After going through various literatures, it has been found that the voltage generated by the thermoelectric module using natural and forced air cooled induction at different operating temperatures has not yet been exploited, this study therefore aims to fill in the gap.

\section{OBJECTIVES}

The objectives of this research was to retrofit a conventional charcoal burner with a thermoelectric generator to recover heat. After which, data from the system will be obtained detailing the electromotive force generated by the thermoelectric generator at different operating temperatures of the burner, and evaluation of the voltage generated by the thermoelectric generator of the charcoal stove at different ambient temperatures

\section{MATERIALS AND METHODS}

\section{Materials}

A TEG1-127-2.0-1.3 thermoelectric module manufactured by EVERREDtronics was bought online from Amazon store. The hot and cold sides of the module were identified. A silicon-based adhesive thermal grease, HTGY260, with thermal conductivity greater than $1 \mathrm{~W} / \mathrm{m} . \mathrm{K}$ and thermal impedance less than $1.36^{\circ} \mathrm{C}-\mathrm{cm}^{2} / \mathrm{W}$ was applied on the both surfaces of the thermoelectric module. This was done to obtain reasonable heat transfer and interfacing of the thermoelectric module with heat sinks. Two extruded aluminum heat-sinks of dimensions $28 \mathrm{x}$ $28 \times 20 \mathrm{~mm}$ were obtained online from Amazon, and their top drilled to allow for insertion of type-J thermocouples. With thermal grease serving as the interfacing material, the thermoelectric module was placed in-between the two heat sinks to form the thermoelectric generator (TEG).

A low-permanence magnet DC driven fan of rated voltage $0.5-5 \mathrm{~V}$ and rpm of 3800 was placed at the fin side of the heat-sink attached to the cold-side of the thermoelectric module to force draft to cool the TEG. The electrical terminals of the fan were joined with the terminals of the thermoelectric module, so that the fan could be powered from the power generated from the module.

A charcoal stove was obtained from a local store in Ibadan, Oyo State. Its combustion section was an inverted truncated square pyramid of base side $7.8 \mathrm{~cm}$, top side of $22.1 \mathrm{~cm}$, and height of $16.1 \mathrm{~cm}$ giving a volume of approximately $3870 \mathrm{~cm}^{3}$. Charcoal was sourced locally from the market in Kaduna, Nigeria. The charcoal was used as fuel in the charcoal stove. The thermoelectric generator was placed in a cut-out section of the wall of the combustion chamber of the charcoal (see Figure 1).

Type-J thermocouples were placed in the holes drilled in each of the heat-sinks, and a voltage sensor was placed was connected in parallel to the electrical terminals of the thermoelectric module. The type-J thermocouples and voltage sensors were hard-wired to an Arduino micro-controller.

\section{Experimental Method}

The temperature of the ambient where the experimental rig was setup was recorded. The coupled thermoelectric generator was placed on the hot path of the combustion product. Type-J thermocouples were used to measure the temperature difference across the generator, while the voltage transducer is used to record the generated voltage. The micro-controller collects the various data every 10 seconds and logs the data unto a computer. The handheld digital multi-meter was used to take measurements of the current and recorded by hand.

The thermoelectric charcoal stove was run at five different ambient temperatures of $36^{\circ} \mathrm{C}, 33^{\circ} \mathrm{C}, 32^{\circ} \mathrm{C}, 30^{\circ} \mathrm{C}$ and $29^{\circ} \mathrm{C}$ with an average fuel hotbed temperature of $1023.75^{\circ} \mathrm{C}$. Figures 2 and 3 show the thermoelectric charcoal stove in operation with the data being collected on a computer. The data were saved as text files and analyzed using $\mathrm{R}$ programming language. 


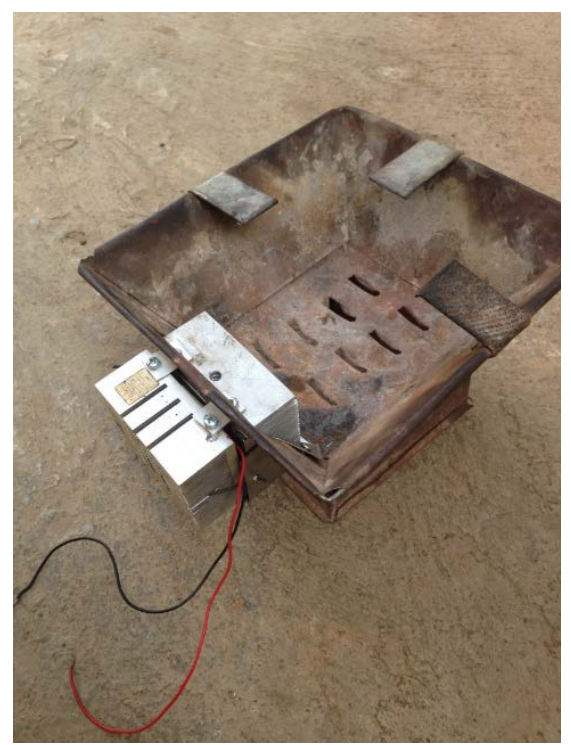

Figure 1. Thermoelectric generator placed in the charcoal stove

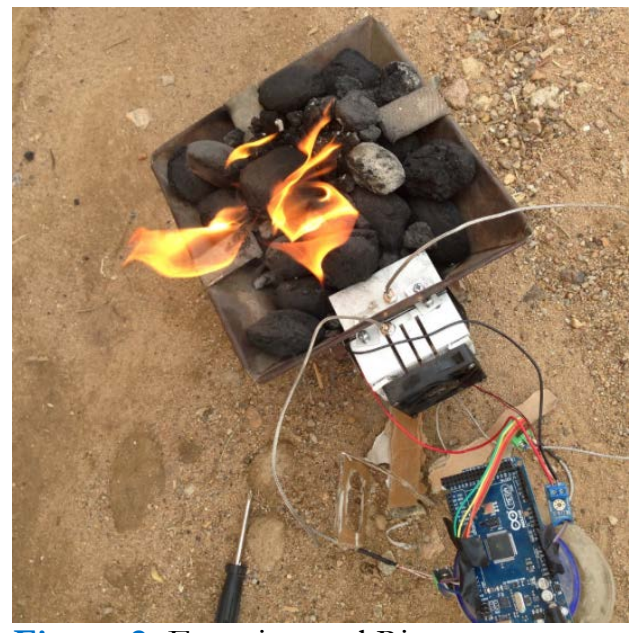

Figure 2. Experimental Rig

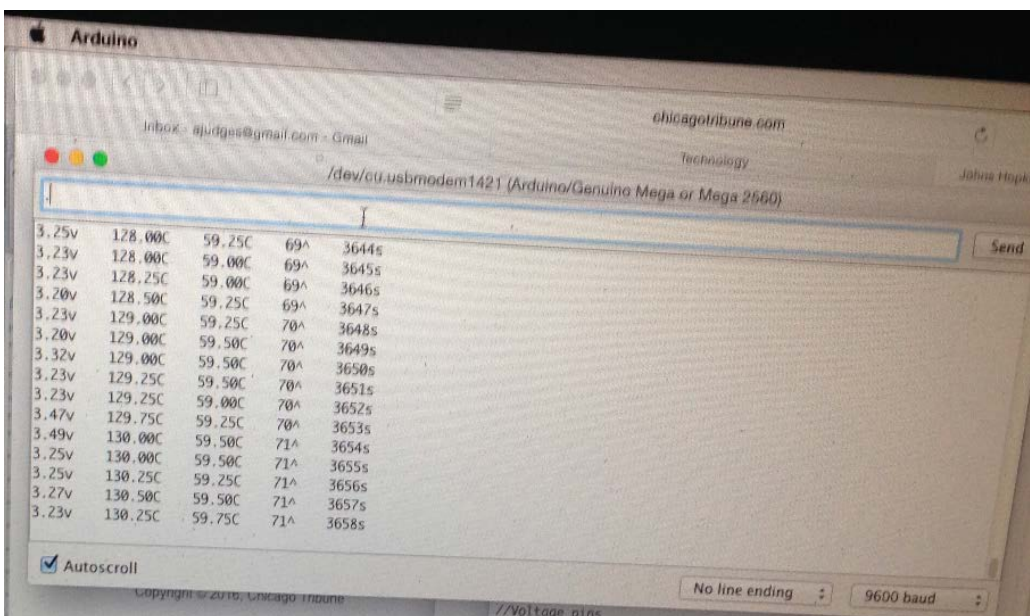

Figure 3. Data being displayed on the computer serial monitor

\section{Calculating Efficiency of Cookstove}

Firepower is the energy released by the burning fuel per unit time. Therefore, for any combustion phase, firepower can be calculated as follows (Chen et al., n.a):

$$
\text { Fire power }(W)=\frac{\left(M_{c i}-M_{c f}\right) \times H_{c}}{\text { time }}
$$

where:

$\mathrm{P}=$ power $(\mathrm{W})$

$\mathrm{M}_{\mathrm{ci}}=$ initial mass of charcoal in the cook stove $(\mathrm{g})$

$\mathrm{M}_{\mathrm{cf}}=$ final mass of charcoal in the cook stove $(\mathrm{g})$

$\mathrm{H}_{\mathrm{c}}=$ energy content of charcoal $(29000 \mathrm{~J} / \mathrm{g})$

Time $=$ time of combustion phase $(\mathrm{s})$

Using the time it takes to boil water by a specified amount of the fuel, efficiency becomes the ratio of energy transferred to the water in the cooking pot to energy released by the burning fuel. Since the energy transferred to the water are in two phases - i.e. energy required to raise the temperature of water and energy required to evaporate the water - the efficiency will be calculated in two phases; hi-power phase (during temperature change of the water) and low-power phase (evaporation of the water). The following formulas which were gotten from literature (Chen et al., n.a), will be used in calculating efficiency,

During hi-power phase (conventional stove):

$$
\operatorname{Efficiency}(\%)=\frac{M_{w} \times C_{w} \times\left(T_{f}-T_{i}\right)}{\left(M_{c i}-M_{c f}\right) \times H_{c}}
$$




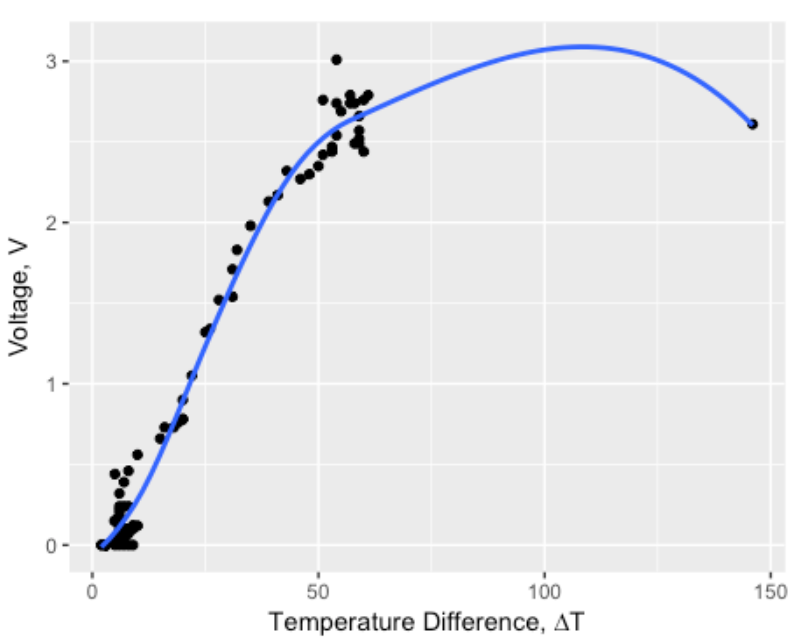

Figure 4. Voltage generated against temperature difference, at $36^{\circ} \mathrm{C}$ ambient temperature

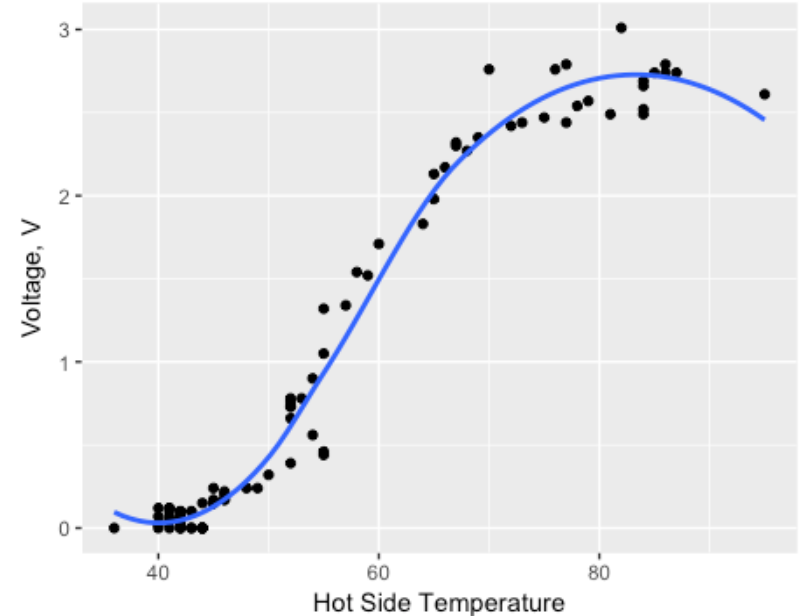

Figure 5. Voltage generated against hot side temperature, at $36^{\circ} \mathrm{C}$ ambient temperature

During hi-power phase (thermoelectric integrated stove):

$$
\operatorname{Efficiency}(\%)=\frac{M_{w} \times C_{w} \times\left(T_{f}-T_{i}\right)+\left(V_{a v} I_{a v} t\right)}{\left(M_{c i}-M_{c f}\right) \times H_{c}}
$$

During low-power phase (conventional stove):

$$
\operatorname{Efficiency}(\%)=\frac{H_{w} \times\left(M_{w i}-M_{w f}\right)}{\left(M_{c i}-M_{c f}\right) \times H_{c}}
$$

During low-power phase (thermoelectric integrated stove):

$$
\operatorname{Efficiency}(\%)=\frac{H_{w} \times\left(M_{w i}-M_{w f}\right)+\left(V_{a v} I_{a v} t\right)}{\left(M_{c i}-M_{c f}\right) \times H_{c}}
$$

where:

$\mathrm{M}_{\mathrm{w}}=$ average water mass in the cook pot from pre-start to finish

$\mathrm{C}_{\mathrm{w}}=$ heat capacity of water $\left(4.184 \mathrm{~J} / \mathrm{g}^{\circ} \mathrm{C}\right)$

$\mathrm{T}_{\mathrm{f}}=$ temperature of first boiling $\left({ }^{\circ} \mathrm{C}\right)$

$\mathrm{T}_{\mathrm{i}}=$ initial temperature of the water in the pot $\left({ }^{\circ} \mathrm{C}\right)$

$\mathrm{H}_{\mathrm{w}}=$ heat of vaporization of water $(2260 \mathrm{~J} / \mathrm{g})$

$\mathrm{V}_{\mathrm{av}}=$ average voltage generated during operation

$\mathrm{I}_{\mathrm{av}}=$ average current generated during operation

$\mathrm{T}=$ time

\section{RESULTS AND DISCUSSION}

The charcoal stove was operated at an average fuel hot-bed temperature of $1023.75^{\circ} \mathrm{C}$ and run at five different ambient temperatures of $29^{\circ} \mathrm{C}, 30^{\circ} \mathrm{C}, 32^{\circ} \mathrm{C}, 33^{\circ} \mathrm{C}$ and $36^{\circ} \mathrm{C}$. Readings were taken every 10 seconds for a total of 15 minutes. Natural air-cooling was used until the voltage generated by the thermoelectric module reached $0.5 \mathrm{~V}$ after which it was able to power the fan to force draft to cool the TEG.

\section{Case 1: At Ambient Temperature of $36^{\circ} \mathrm{C}$}

A maximum voltage of $3.01 \mathrm{~V}$ was achieved, and this occurred at a temperature difference of $54^{\circ} \mathrm{C}$ and a hotside temperature of $136^{\circ} \mathrm{C}$. The value of voltage increased linearly with the temperature difference before reaching its peak, after which it started forming a downward curve (Figure 4). The mean voltage generated was $0.9964 \mathrm{~V}$ and the median voltage value is $0.36 \mathrm{~V}$. The mean temperature difference is $\Delta \mathrm{T}_{\text {mean }}=23.84^{\circ} \mathrm{C}$, while the maximum temperature difference is $150^{\circ} \mathrm{C}$ with a corresponding hot side temperature of $241^{\circ} \mathrm{C}$ and voltage of $2.61 \mathrm{~V}$. The graph of voltage generated against the hot side temperature is shown in Figure 5. Voltage increases linearly with increase in hot side temperature, after which it starts to form a downward curve. At a voltage of $0.5 \mathrm{~V}$, where the powering of the fan by the TEG starts, gives a hot side temperature of $64^{\circ} \mathrm{C}$ and temperature difference of 10 . 
Table 1. Summary of parameters at $36^{\circ} \mathrm{C}$ ambient temperature

\begin{tabular}{lccc}
\hline & Voltage & Hot side temp (T1) & Temperature difference, $\Delta \mathbf{T}$ \\
\hline Min. & 0.000 & 45.00 & 2.00 \\
\hline $\mathbf{1}^{\text {st }}$ quartile & 0.078 & 49.00 & 6.00 \\
\hline Median & 0.355 & 57.50 & 9.00 \\
\hline Mean & 0.996 & 79.41 & 23.84 \\
\hline $\mathbf{3}^{\text {rd }}$ quartile & 2.293 & 112.25 & 45.25 \\
\hline Max. & 3.010 & 241.00 & 146.00 \\
\hline
\end{tabular}

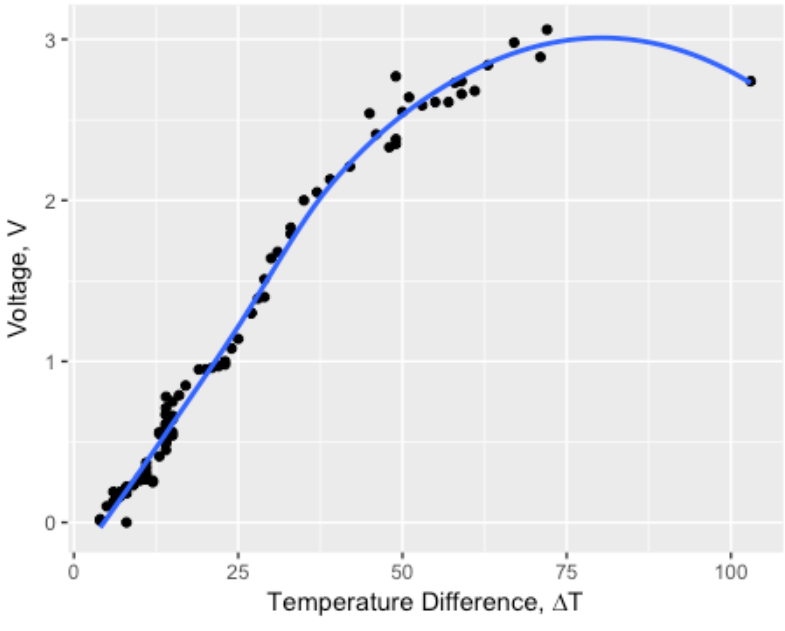

Figure 6. Voltage generated against temperature difference, at $33^{\circ} \mathrm{C}$ ambient temperature

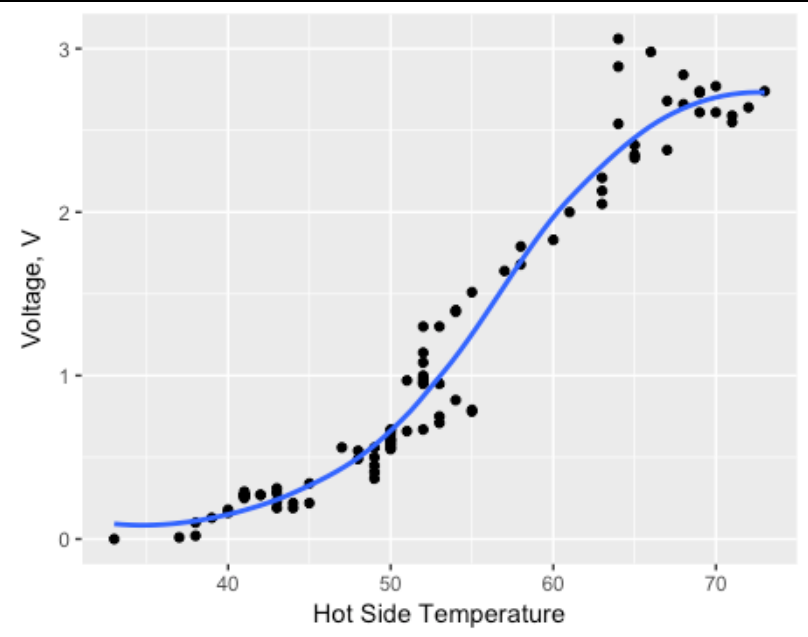

Figure 7. Voltage generated against hot side temperature, at $33^{\circ} \mathrm{C}$ ambient temperature

Table 2. Summary of parameters at $33^{\circ} \mathrm{C}$ ambient temperature

\begin{tabular}{lccc}
\hline & Voltage & Hot side temp (T1) & Temperature difference, $\Delta$ T \\
\hline Min. & 0.000 & 41.00 & 4.00 \\
\hline $\mathbf{1}^{\text {st }}$ quartile & 0.295 & 53.25 & 11.00 \\
\hline Median & 0.730 & 67.50 & 15.00 \\
\hline Mean & 1.146 & 78.83 & 25.81 \\
\hline $\mathbf{3}^{\text {rd }}$ quartile & 2.038 & 98.25 & 36.50 \\
\hline Max. & 3.060 & 176.00 & 103.00 \\
\hline
\end{tabular}

Table 1 provides a summary of the parameters operating at $36^{\circ} \mathrm{C}$ ambient temperature. The data used can be seen at appendix A.1

\section{Case 2: At Ambient Temperature of $33^{\circ} \mathrm{C}$}

Here, maximum voltage of $3 \mathrm{~V}$ was achieved at a temperature difference of $72^{\circ} \mathrm{C}$ and hot side temperature of $136^{\circ} \mathrm{C}$. The voltage increased linearly up to $2.7 \mathrm{~V}$ before it started it started curving downwards Figure 6 . The mean voltage obtained is $1.15 \mathrm{~V}$ with the median voltage value at $0.73 \mathrm{~V}$. The mean temperature difference is $\Delta \mathrm{T}_{\text {mean }}=25.81^{\circ} \mathrm{C}$, while the maximum temperature difference $\left(\Delta \mathrm{T}=103^{\circ} \mathrm{C}\right.$ ) (see Figure 7) occurred at a hot side temperature of $176^{\circ} \mathrm{C}$ and gave a voltage of $2.74 \mathrm{~V}$. At the voltage of $0.5 \mathrm{~V}$, where the fan starts to be powered, the hot side temperature and temperature difference were $63^{\circ} \mathrm{C}$ and $14^{\circ} \mathrm{C}$ respectively.

Table 2 provides a summary of the parameters operating at $33^{\circ} \mathrm{C}$ ambient temperature. The data used to generate the table can be found in appendix A.2

\section{Case 3: At Ambient Temperature of $32^{\circ} \mathrm{C}$}

The voltage increased linearly to up to its peak $3.49 \mathrm{~V}$ at a temperature difference of $86^{\circ} \mathrm{C}$ (Figure 8). From Figure 9 the peak voltage occurred at a hot side temperature of about $55^{\circ} \mathrm{C}$. The mean voltage generated is 1.34 $\mathrm{V}$ and the median voltage is $1.15 \mathrm{~V}$. The mean temperature difference is $\Delta \mathrm{T}_{\text {mean }}=29.04^{\circ} \mathrm{C}$, while the maximum temperature difference obtained is $86^{\circ} \mathrm{C}$, and the corresponding voltage and hot side temperature are $3.49 \mathrm{~V}$ and $141^{\circ} \mathrm{C}$ respectively. At the $0.5 \mathrm{~V}$ voltage point, the hot side temperature was $60^{\circ} \mathrm{C}$ and temperature difference of $17^{\circ} \mathrm{C}$.

Table 3 provides a summary of the parameters operating at $32^{\circ} \mathrm{C}$ ambient temperature. The data used to generate the table can be found in appendix A.3

\section{Case 4: At Ambient Temperature of $30^{\circ} \mathrm{C}$}

Voltage peaked at $4.36 \mathrm{~V}$ after increasing linearly. The maximum voltage occurred at a temperature difference of $89^{\circ} \mathrm{C}$ (Figure 10) and a hot side temperature of $150^{\circ} \mathrm{C}$ (Figure 11). The mean and median voltages are $1.94 \mathrm{~V}$ 


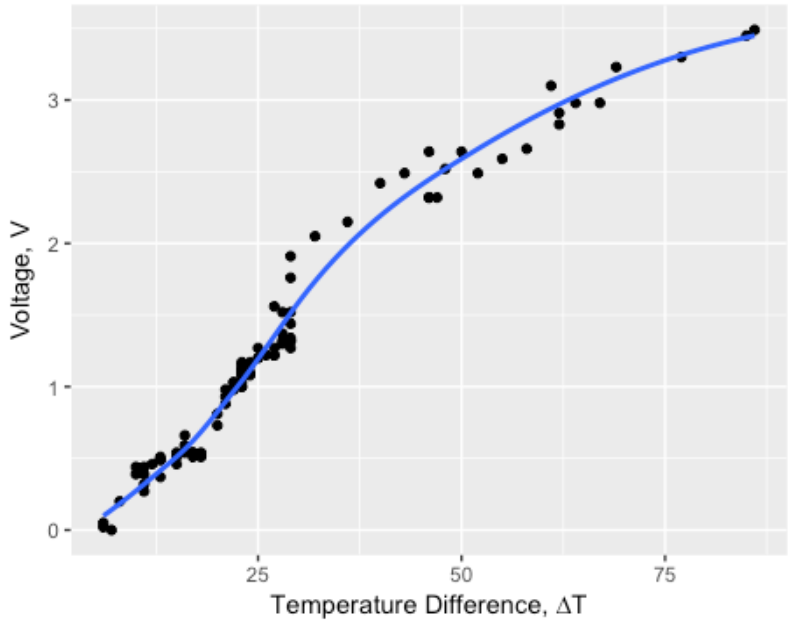

Figure 8. Voltage generated against temperature difference, at $32^{\circ} \mathrm{C}$ ambient temperature

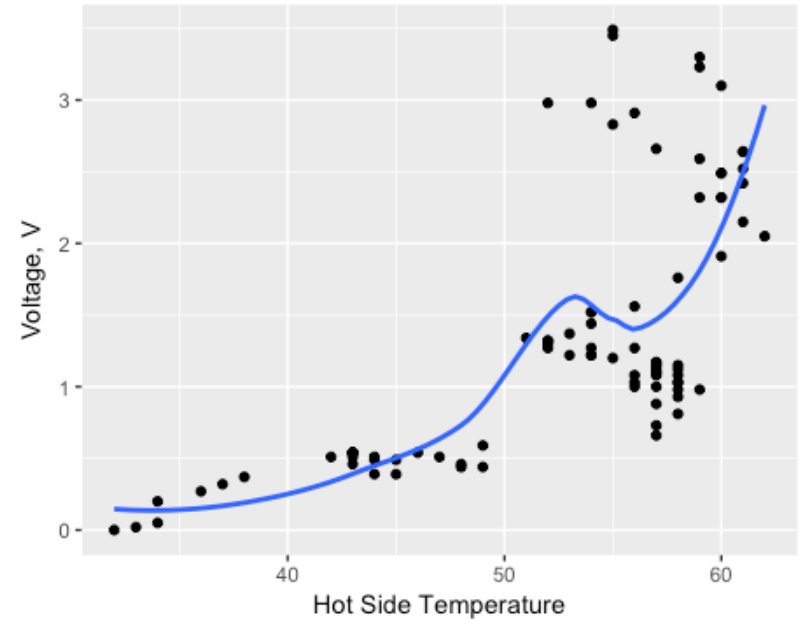

Figure 9. Voltage generated against hot side temperature, at $32^{\circ} \mathrm{C}$ ambient temperature

Table 3. Summary of parameters at $32^{\circ} \mathrm{C}$ ambient temperature

\begin{tabular}{lccc}
\hline & Voltage & Hot side temp (T1) & Temperature difference, $\Delta \mathbf{T}$ \\
\hline Min. & 0.000 & 39.00 & 6.00 \\
\hline $\mathbf{1}^{\text {st }}$ quartile & 0.540 & 60.25 & 17.00 \\
\hline Median & 1.150 & 80.00 & 24.00 \\
\hline Mean & 1.343 & 81.62 & 29.04 \\
\hline $\mathbf{3}^{\text {rd }}$ quartile & 1.873 & 89.00 & 29.00 \\
\hline Max. & 3.490 & 141.00 & 86.00 \\
\hline
\end{tabular}

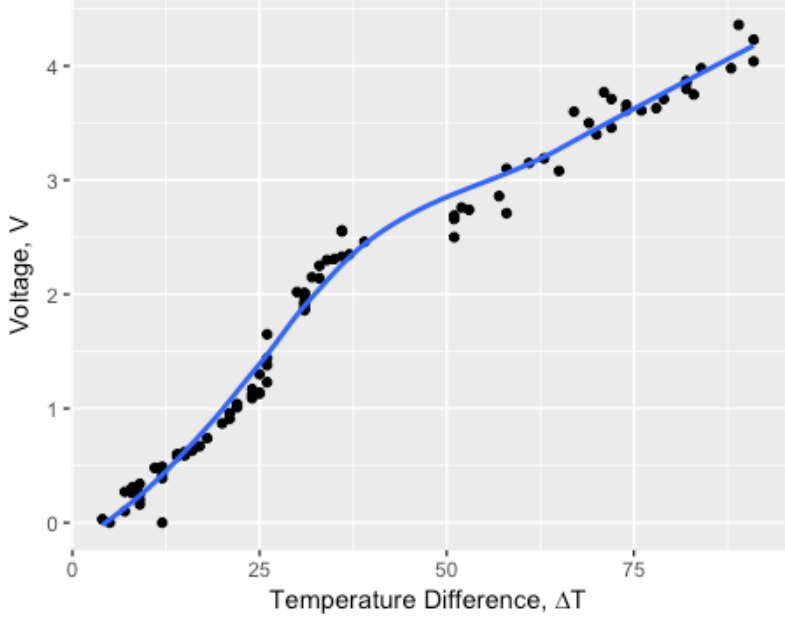

Figure 10. Voltage generated against temperature difference, at $30^{\circ} \mathrm{C}$ ambient temperature

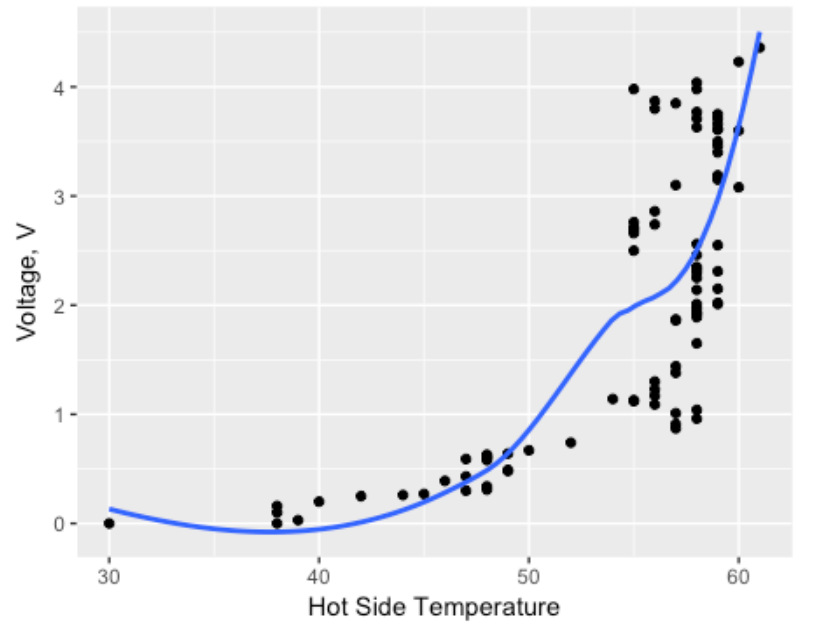

Figure 11. Voltage generated against hot side temperature, at $30^{\circ} \mathrm{C}$ ambient temperature

and $1.950 \mathrm{~V}$ respectively. The mean temperature difference is $\Delta \mathrm{T}_{\text {mean }}=38.47^{\circ} \mathrm{C}$, while maximum temperature difference of $91^{\circ} \mathrm{C}$ was achieved with corresponding voltage and hot side temperature of $4.23 \mathrm{~V}$ and $151^{\circ} \mathrm{C}$ respectively. At the voltage point $(0.5 \mathrm{~V})$ of powering the fan, the temperature difference and hot side temperature were $12^{\circ} \mathrm{C}$ and $61^{\circ} \mathrm{C}$ respectively.

Table 4 provides a summary of the parameters operating at $30^{\circ} \mathrm{C}$ ambient temperature. The data used to generate the table can be found in appendix A.4

\section{Case 5: At Ambient Temperature of $29^{\circ} \mathrm{C}$}

Voltage increased linearly with respect to temperature difference and peaked at $5.25 \mathrm{~V}$ with corresponding temperature difference of $92^{\circ} \mathrm{C}$ (Figure 12), and hot side temperature of $159^{\circ} \mathrm{C}$ (Figure 13). The mean and median voltages are $2.56 \mathrm{~V}$ and $2.788 \mathrm{~V}$ respectively. The mean temperature difference obtained is $\Delta \mathrm{T}_{\text {mean }}=48.13^{\circ} \mathrm{C}$, while the maximum obtained temperature difference is $106^{\circ} \mathrm{C}$, with corresponding voltage of $4.79 \mathrm{~V}$ and hot side temperature of $164^{\circ} \mathrm{C}$. At the $0.5 \mathrm{~V}$ point where the thermoelectric starts to power the fan, the hot side temperature was $62^{\circ} \mathrm{C}$ and temperature difference of $7^{\circ} \mathrm{C}$. 
Table 4. Summary of parameters at $30^{\circ} \mathrm{C}$ ambient temperature

\begin{tabular}{lccc}
\hline & Voltage & Hot side temp (T1) & Temperature difference, $\Delta$ T \\
\hline Min. & 0.000 & 42.00 & 4.00 \\
\hline $\mathbf{1}^{\text {st }}$ quartile & 0.648 & 65.50 & 16.25 \\
\hline Median & 1.950 & 89.00 & 31.00 \\
\hline Mean & 1.944 & 92.64 & 38.47 \\
\hline $\mathbf{3}^{\text {rd }}$ quartile & 3.095 & 118.75 & 60.25 \\
\hline Max. & 4.360 & 151.00 & 91.00 \\
\hline
\end{tabular}

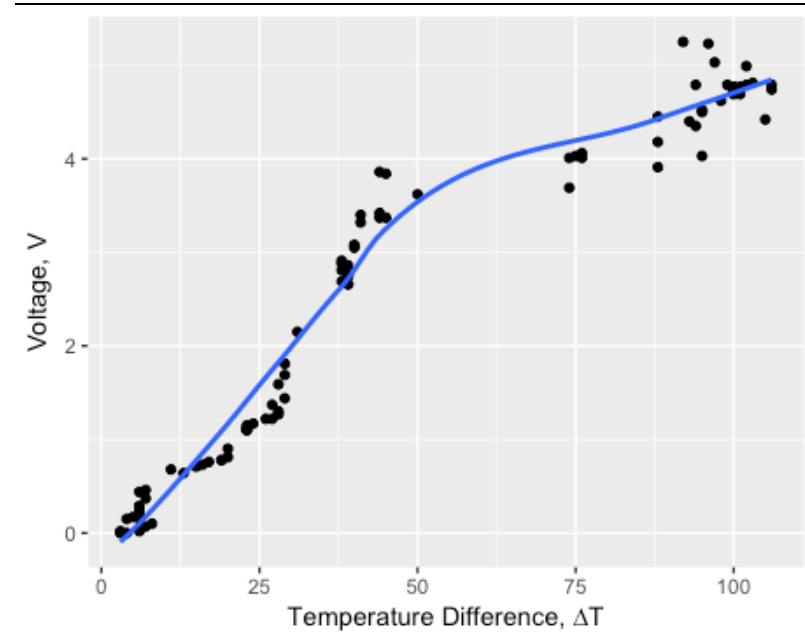

Figure 12. Voltage generated against temperature, at $29^{\circ} \mathrm{C}$ ambient temperature

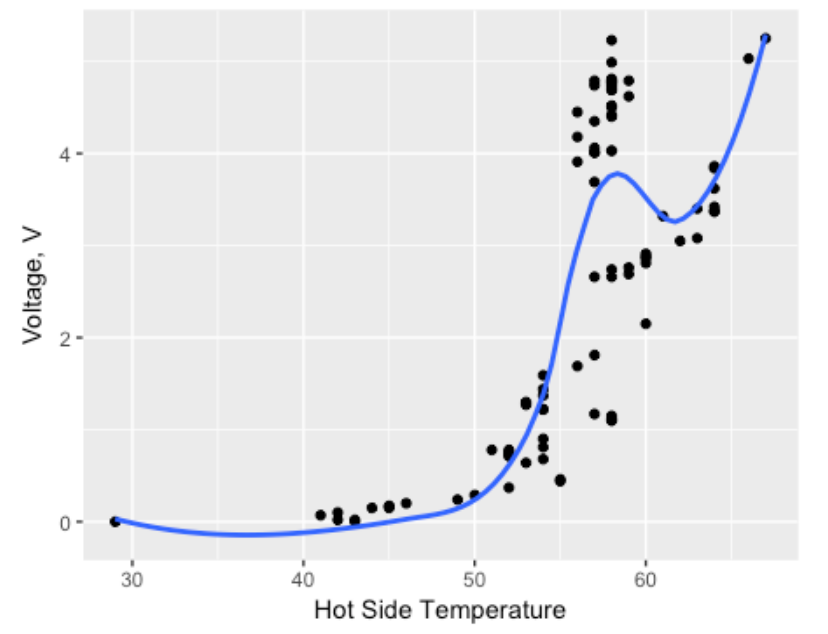

Figure 13. Voltage generated against hot side temperature, at $29^{\circ} \mathrm{C}$ ambient temperature

Table 5. Summary of parameters operating at $29^{\circ} \mathrm{C}$ ambient temperature

\begin{tabular}{lccc}
\hline & Voltage & Hot side temp (T1) & Temperature difference, $\Delta$ T \\
\hline Min. & 0.000 & 45.00 & 3.00 \\
\hline $\mathbf{1}^{\text {st }}$ quartile & 0.788 & 71.75 & 19.25 \\
\hline Median & 2.785 & 98.00 & 39.00 \\
\hline Mean & 2.560 & 103.78 & 48.13 \\
\hline $\mathbf{3}^{\text {rd }}$ quartile & 4.308 & 149.50 & 91.00 \\
\hline Max. & 5.250 & 164.00 & 106.00 \\
\hline
\end{tabular}

Table 6. Power and efficiency values of the conventional and thermoelectric burner

\begin{tabular}{|c|c|c|c|}
\hline & & Conventional Burner & Thermoelectric burner \\
\hline & & Ambient temperature of $29^{\circ} \mathrm{C}$ & Ambient temperature of $29^{\circ} \mathrm{C}$ \\
\hline \multicolumn{2}{|c|}{ Hi-power phase Fire power (W) } & $2924 \mathrm{~W}$ & $2924 \mathrm{~W}$ \\
\hline & Efficiency $(\%)$ & $20.24 \%$ & $20.32 \%$ \\
\hline \multirow{2}{*}{$\begin{array}{l}\text { Low-power } \\
\text { phase }\end{array}$} & Fire power $(\mathrm{W})$ & $656 \mathrm{~W}$ & $656 \mathrm{~W}$ \\
\hline & Efficiency (\%) & $57.00 \%$ & $57.6 \%$ \\
\hline
\end{tabular}

Table 5 provides a summary of the parameters operating at $30^{\circ} \mathrm{C}$ ambient temperature. The data used to generate the table can be found in appendix A.5.

The graphs of voltage generated versus hot side temperature, T1, for ambient temperatures of $29^{\circ} \mathrm{C}, 30^{\circ} \mathrm{C}$ and $32^{\circ} \mathrm{C}$ follow a similar linear pattern, however for ambient temperatures of $33^{\circ} \mathrm{C}$ and $36^{\circ} \mathrm{C}$, a downward curve begins to appear at about $60^{\circ} \mathrm{C}$. Similarly graphs of voltage generated versus $\Delta \mathrm{T}$ for ambient temperatures of $29^{\circ} \mathrm{C}, 30^{\circ} \mathrm{C}$ and $32^{\circ} \mathrm{C}$ have the same pattern, while ambient temperatures of $33^{\circ} \mathrm{C}$ and $36^{\circ} \mathrm{C}$ take a different pattern. It can be seen that voltage generally increases with an increase in the hot side temperature for all ambient temperatures, with the highest voltage recordings being $5.25 \mathrm{~V}$ at an ambient temperature of $29^{\circ} \mathrm{C}$. It is observed that from an ambient temperature of $36^{\circ} \mathrm{C}$, each subsequent lower ambient temperature recorded a higher and maximum voltage values. Likewise, the mean voltage values increased with lower ambient temperature. Explanation for this phenomenon could come from the fact that since ambient air is used to cool the thermoelectric generator enabling temperature difference across the module, the lower the ambient temperature the more effective temperature difference is achieved across the module. This is substantiated from the data on temperature difference, where the mean temperature difference across the module is higher with decreasing ambient temperature. The mean temperature difference for $29^{\circ} \mathrm{C}$ ambient temperature, which had the highest maximum and mean voltage readings, is $\Delta \mathrm{T}_{\text {mean }}=$ $48.13^{\circ} \mathrm{C}$; while for $36^{\circ} \mathrm{C}$ ambient temperature which had the lowest maximum and mean voltage readings, is $\Delta \mathrm{T}_{\text {mean }}$ $=23.84^{\circ} \mathrm{C}$. 
Calculating and Comparing the Efficiency of the Thermoelectric Charcoal Stove with a Conventional Charcoal Stove of Similar Size at the Same Ambient Temperature of $29^{\circ} \mathrm{C}$.

From Equations 2-6,

High-power phase Firepower

$$
\text { Fire power }(\mathrm{W})=\frac{\left(M_{c i}-M_{c f}\right) \times H_{c}}{\text { time }}=\frac{138 \mathrm{~g} \times 29000 \mathrm{~J} / \mathrm{g}}{17 \mathrm{~min} \times 60 \mathrm{~s} / \mathrm{min}}=2924 \mathrm{~W}
$$

Low-power phase Firepower,

$$
\text { Fire power }(\mathrm{W})=\frac{\left(M_{c i}-M_{c f}\right) \times H_{c}}{\text { time }}=\frac{19 \mathrm{~g} \times 29000 \mathrm{~J} / \mathrm{g}}{14 \mathrm{~min} \times 60 \mathrm{~s} / \mathrm{min}}=656 \mathrm{~W}
$$

Efficiency for Conventional Charcoal Stove of Volume Capacity $3870 \mathrm{~cm}^{3}$ at $29^{\circ} \mathrm{C}$ Ambient Temperature High-power phase:

$$
\operatorname{Efficiency}(\%)=\frac{M_{w} \times C_{w} \times\left(T_{f}-T_{i}\right)}{\left(M_{c i}-M_{c f}\right) \times H_{c}}=\frac{2652 g \times 4.184 J / g^{\circ} \mathrm{C} \times(100-27)^{\circ} \mathrm{C}}{138 \mathrm{~g} \times 29000 \mathrm{~J} / \mathrm{g}}=20.24 \%
$$

Low-power phase:

$$
\text { Efficiency }(\%)=\frac{H_{w} \times\left(M_{w i}-M_{w f}\right)}{\left(M_{c i}-M_{c f}\right) \times H_{c}}=\frac{2260 \mathrm{~J} / \mathrm{g} \times 139 \mathrm{~g}}{19 \mathrm{~g} \times 29000 \mathrm{~J} / \mathrm{g}}=57.00 \%
$$

Efficiency for Thermoelectric Charcoal Stove of Volume Capacity $3870 \mathrm{~cm}^{3}$ at $29^{\circ} \mathrm{C} \mathrm{Ambient} \mathrm{Temperature}$ High-power phase:

$$
\begin{gathered}
\text { Efficiency }(\%)=\frac{M_{w} \times C_{w} \times\left(T_{f}-T_{i}\right)+\left(I_{a v} V_{a v} t\right)}{\left(M_{c i}-M_{c f}\right) \times H_{c}} \\
=\frac{2652 g \times \frac{4.184 J}{g}{ }^{\circ} \mathrm{C} \times(100-27)^{\circ} \mathrm{C}+(2.56 * 0.43) *(17 * 60)}{138 g \times 29000 \mathrm{~J} / g}=20.27 \%
\end{gathered}
$$

Low-power phase:

$$
\begin{aligned}
& \operatorname{Efficiency}(\%)=\frac{H_{w} \times\left(M_{w i}-M_{w f}\right)+\left(V_{a v} I_{a v} t\right)}{\left(M_{c i}-M_{c f}\right) \times H_{c}} \\
= & \frac{2260 \mathrm{~J} / g \times 139 g+(2.56 * 1) *(17 * 60)}{19 g \times 29000 \mathrm{~J} / \mathrm{g}}=57.49 \%
\end{aligned}
$$

Tabulating the result of the computations,

Table 6 shows the various power and efficiency values of the conventional and thermoelectric burner at $29^{\circ} \mathrm{C}$ ambient temperature. The thermoelectric burner is seen to have a slightly higher efficiency than the conventional charcoal burner.

\section{CONCLUSION}

The development of a conventional charcoal burner with a thermoelectric generator attached to it has been achieved and tested under real-life cooking conditions in sub-Saharan Africa. The e.m.f generated by the thermoelectric charcoal stove generally increases with increase in the hot side temperature of the thermoelectric module. When using ambient air to cool the thermoelectric module, the performance of the thermoelectric module increases with a decrease in ambient temperature. This is as a result of the lower ambient temperature enabling a higher temperature difference across the thermoelectric generator.

While the improved efficiency of a thermoelectric charcoal stove over a conventional charcoal stove is not so higher, the electrical energy from it can be put to good use, such as charging batteries and powering LEDs 


\section{REFERENCES}

BioLite. (2015). BioLite CampStove. Available at: http://www.biolitestove.com/products/biolite-campstove

Chen, Y., Pew, D., Abbott D. (n.a.). Cook Stove Efficiency, Health and Environmental Impacts: Biomass Lab Report. Available at: http://stoves.bioenergylists.org/files/er120-1biomass.pdfChampier, D., Bedecarrats, J. P., Kousksou, T., Rivaletto, M., Strub, F. and Pignolet, P. (2011). Study of a Thermoelectric Generator incorporated in a multifunction wood stove. Energy Elsevier, 36, 3, 1518.

E+Carbon. (2009). Improved Household Charcoal Stoves in Ghana, London. Available at: http:// cleancookstoves.org/binary-data/RESOURCE/ file/000/000/108-1.pdf

Killander, A. and Bass, J. C. (1996). A stove-top generator for cold areas. In: Proceedings of the 15th International Conference on Thermoelectrics, New York. https://doi.org/10.1109/ICT.1996.553511

Lertsatitthanakorn, C. (2007). Electrical performance analysis and economic evaluation of combined biomass cook stove thermoelectric (BITE) generator. Bioresource Technology, 98, 1670-1674. https://doi.org/10.1016/j.biortech.2006.05.048

Mastbergen, D., Wilson, B. and Joshi, S. (2005). Producing Light from Stoves using a Thermoelectric Generator. In: ETHOS International Stove Research Conference, Seattle, Washington, 15-27.

Milind, P. K. (2009). Experimental study for improving energy efficiency of charcoal stove. Journal of Scientific and Industrial Research, 68, 412-416.

Nuwayhid, R. Y., Rowe, D. M and Min, G. (2003). Low Cost Stove-Top Thermoelectric Generator for Regions with Unreliable Electricity Supply. Renewable Energy, 28, 205-222. https://doi.org/10.1016/S09601481(02)00024-1

Nuwayhid, R. Y. and Hamade, R. (2005). Design and testing of a locally made loop-type thermosyphonic heat sink for stove-top thermoelectric generator. Renewable Energy, 30, 1101-1116. https://doi.org/10.1016/j.renene.2004.09.008

O'Shaughnessy, S. M., Deasy, M. J., Kinsella, C. E., Doyle, J. V. and Robinson, A. J. (2013). Small scale electricity generation from a portable biomass cookstove: Prototype design and preliminary results. Applied Energy, 12, no. C, 374-385. https://doi.org/10.1016/j.apenergy.2012.07.032

Rinalde, G. F., Juanico, L. G., Taglialavore, E., Gortari, S. and Molina S. G. (2010). Development of thermoelectric generators for electrification of isolated rural homes. International Journal of Hydrogen Energy, 35(11), 5818-5822. https:// doi.org/10.1016/j.ijhydene.2010.02.093

\section{APPENDIX A}

Table A.1. Data at ambient temperature of $36^{\circ} \mathrm{C}$ and average fuel hotbed temperature of $1023.75^{\circ} \mathrm{C}$

\begin{tabular}{|c|c|c|c|c|}
\hline Time (sec) & Voltage & T1 & $\mathrm{T} 2$ & T1-T2 \\
\hline 10 & 0 & 45 & 36 & 9 \\
\hline 20 & 0 & 45 & 42 & 2 \\
\hline 30 & 0 & 45 & 43 & 2 \\
\hline 30 & 0 & 46 & 43 & 3 \\
\hline 40 & 0 & 46 & 44 & 3 \\
\hline 50 & 0 & 47 & 44 & 3 \\
\hline 60 & 0 & 47 & 44 & 3 \\
\hline 70 & 0 & 47 & 44 & 3 \\
\hline 80 & 0 & 47 & 44 & 3 \\
\hline 90 & 0 & 48 & 42 & 5 \\
\hline 100 & 0 & 48 & 42 & 6 \\
\hline 110 & 0 & 48 & 40 & 8 \\
\hline 120 & 0 & 48 & 41 & 7 \\
\hline 130 & 0.02 & 47 & 40 & 7 \\
\hline 140 & 0.02 & 48 & 42 & 6 \\
\hline 150 & 0.02 & 47 & 42 & 6 \\
\hline 160 & 0.02 & 48 & 42 & 5 \\
\hline 170 & 0.05 & 47 & 41 & 6 \\
\hline 180 & 0.05 & 47 & 41 & 6 \\
\hline 190 & 0.05 & 47 & 41 & 6 \\
\hline 200 & 0.07 & 48 & 41 & 7 \\
\hline 210 & 0.07 & 48 & 40 & 8 \\
\hline
\end{tabular}


European Journal of Sustainable Development Research, 2(2), 25

\begin{tabular}{|c|c|c|c|c|}
\hline 220 & 0.07 & 48 & 42 & 7 \\
\hline 230 & 0.07 & 49 & 42 & 7 \\
\hline 240 & 0.1 & 49 & 42 & 7 \\
\hline 250 & 0.1 & 49 & 43 & 6 \\
\hline 260 & 0.1 & 49 & 43 & 7 \\
\hline 270 & 0.1 & 50 & 42 & 8 \\
\hline 280 & 0.1 & 50 & 42 & 8 \\
\hline 290 & 0.1 & 50 & 41 & 9 \\
\hline 300 & 0.12 & 49 & 41 & 9 \\
\hline 310 & 0.12 & 50 & 41 & 9 \\
\hline 320 & 0.12 & 50 & 40 & 10 \\
\hline 330 & 0.15 & 50 & 45 & 5 \\
\hline 340 & 0.15 & 50 & 45 & 5 \\
\hline 350 & 0.15 & 50 & 45 & 5 \\
\hline 360 & 0.15 & 50 & 44 & 6 \\
\hline 370 & 0.17 & 50 & 45 & 6 \\
\hline 380 & 0.17 & 51 & 46 & 6 \\
\hline 390 & 0.17 & 52 & 46 & 6 \\
\hline 400 & 0.2 & 52 & 46 & 6 \\
\hline 410 & 0.22 & 52 & 46 & 6 \\
\hline 420 & 0.24 & 52 & 45 & 8 \\
\hline 430 & 0.24 & 54 & 48 & 6 \\
\hline 440 & 0.24 & 55 & 49 & 7 \\
\hline 450 & 0.32 & 56 & 50 & 6 \\
\hline 460 & 0.39 & 59 & 52 & 7 \\
\hline 470 & 0.44 & 60 & 55 & 5 \\
\hline 480 & 0.46 & 63 & 55 & 8 \\
\hline 490 & 0.56 & 64 & 54 & 10 \\
\hline 500 & 0.66 & 66 & 52 & 15 \\
\hline 510 & 0.73 & 68 & 52 & 16 \\
\hline 520 & 0.73 & 70 & 52 & 18 \\
\hline 530 & 0.76 & 71 & 52 & 19 \\
\hline 540 & 0.78 & 72 & 52 & 20 \\
\hline 550 & 0.78 & 73 & 53 & 20 \\
\hline 560 & 0.9 & 75 & 54 & 20 \\
\hline 570 & 1.05 & 77 & 55 & 22 \\
\hline 580 & 1.32 & 80 & 55 & 25 \\
\hline 590 & 1.34 & 83 & 57 & 26 \\
\hline 600 & 1.52 & 87 & 59 & 28 \\
\hline 610 & 1.54 & 89 & 58 & 31 \\
\hline 620 & 1.71 & 91 & 60 & 31 \\
\hline 630 & 1.83 & 95 & 64 & 32 \\
\hline 640 & 1.98 & 100 & 65 & 35 \\
\hline 650 & 2.13 & 104 & 65 & 39 \\
\hline 660 & 2.17 & 107 & 66 & 41 \\
\hline 670 & 2.32 & 110 & 67 & 43 \\
\hline 680 & 2.27 & 113 & 68 & 46 \\
\hline 690 & 2.3 & 115 & 67 & 48 \\
\hline 700 & 2.35 & 119 & 69 & 50 \\
\hline 710 & 2.76 & 122 & 70 & 51 \\
\hline 720 & 2.42 & 122 & 72 & 51 \\
\hline 730 & 2.44 & 126 & 73 & 53 \\
\hline 740 & 2.47 & 128 & 75 & 53 \\
\hline 750 & 2.54 & 132 & 78 & 54 \\
\hline 760 & 3.01 & 136 & 82 & 54 \\
\hline 770 & 2.69 & 140 & 84 & 55 \\
\hline 780 & 2.74 & 141 & 87 & 54 \\
\hline 790 & 2.79 & 143 & 86 & 57 \\
\hline 800 & 2.74 & 143 & 85 & 58 \\
\hline 810 & 2.66 & 143 & 84 & 59 \\
\hline 820 & 2.74 & 143 & 86 & 57 \\
\hline 830 & 2.61 & 241 & 95 & 146 \\
\hline 840 & 2.49 & 141 & 84 & 58 \\
\hline 850 & 2.52 & 142 & 84 & 59 \\
\hline
\end{tabular}


Ajah / Performance Evaluation of Thermoelectric Charcoal Stove

\begin{tabular}{lllll}
\hline 860 & 2.49 & 140 & 81 & 59 \\
\hline 870 & 2.57 & 139 & 79 & 59 \\
\hline 880 & 2.79 & 137 & 77 & 61 \\
\hline 890 & 2.44 & 137 & 77 & 60 \\
\hline 900 & 2.76 & 136 & 76 & 60 \\
\hline
\end{tabular}

Table A.2. Data at ambient temperature of $33^{\circ} \mathrm{C}$ and average fuel hot-bed temperature of $1023.75^{\circ} \mathrm{C}$.

\begin{tabular}{|c|c|c|c|c|}
\hline Time (sec) & Voltage & T1 & $\mathrm{T} 2$ & T1-T2 \\
\hline 10 & 0.00 & 41 & 33 & 8 \\
\hline 20 & 0.01 & 41 & 37 & 4 \\
\hline 30 & 0.02 & 42 & 38 & 4 \\
\hline 30 & 0.10 & 43 & 38 & 5 \\
\hline 40 & 0.13 & 46 & 39 & 6 \\
\hline 50 & 0.16 & 47 & 40 & 7 \\
\hline 60 & 0.18 & 48 & 40 & 8 \\
\hline 70 & 0.19 & 50 & 44 & 6 \\
\hline 80 & 0.19 & 50 & 43 & 7 \\
\hline 90 & 0.22 & 52 & 44 & 8 \\
\hline 100 & 0.22 & 53 & 45 & 8 \\
\hline 110 & 0.23 & 53 & 43 & 9 \\
\hline 120 & 0.25 & 53 & 41 & 12 \\
\hline 130 & 0.26 & 52 & 41 & 12 \\
\hline 140 & 0.27 & 52 & 41 & 11 \\
\hline 150 & 0.27 & 53 & 41 & 11 \\
\hline 160 & 0.27 & 53 & 42 & 11 \\
\hline 170 & 0.29 & 52 & 41 & 11 \\
\hline 180 & 0.27 & 52 & 41 & 10 \\
\hline 190 & 0.26 & 51 & 41 & 10 \\
\hline 200 & 0.27 & 51 & 41 & 10 \\
\hline 210 & 0.27 & 51 & 41 & 10 \\
\hline 220 & 0.27 & 52 & 42 & 10 \\
\hline 230 & 0.28 & 53 & 43 & 10 \\
\hline 240 & 0.31 & 54 & 43 & 11 \\
\hline 250 & 0.34 & 56 & 45 & 11 \\
\hline 260 & 0.37 & 60 & 49 & 11 \\
\hline 270 & 0.41 & 62 & 49 & 13 \\
\hline 280 & 0.45 & 63 & 49 & 14 \\
\hline 290 & 0.50 & 63 & 49 & 14 \\
\hline 300 & 0.49 & 62 & 48 & 14 \\
\hline 310 & 0.56 & 63 & 47 & 15 \\
\hline 320 & 0.54 & 64 & 48 & 15 \\
\hline 330 & 0.55 & 63 & 50 & 13 \\
\hline 340 & 0.56 & 63 & 49 & 13 \\
\hline 350 & 0.56 & 64 & 50 & 14 \\
\hline 360 & 0.58 & 64 & 50 & 14 \\
\hline 370 & 0.59 & 64 & 50 & 14 \\
\hline 380 & 0.61 & 64 & 50 & 14 \\
\hline 390 & 0.61 & 64 & 50 & 14 \\
\hline 400 & 0.67 & 64 & 50 & 14 \\
\hline 410 & 0.64 & 65 & 50 & 15 \\
\hline 420 & 0.66 & 65 & 50 & 15 \\
\hline 430 & 0.66 & 66 & 51 & 15 \\
\hline 440 & 0.67 & 67 & 52 & 14 \\
\hline 450 & 0.71 & 67 & 53 & 14 \\
\hline 460 & 0.75 & 68 & 53 & 15 \\
\hline 470 & 0.78 & 69 & 55 & 14 \\
\hline 480 & 0.79 & 70 & 55 & 16 \\
\hline 490 & 0.85 & 71 & 54 & 17 \\
\hline 500 & 0.95 & 72 & 53 & 19 \\
\hline 510 & 0.95 & 72 & 52 & 20 \\
\hline 520 & 0.96 & 73 & 52 & 21 \\
\hline 530 & 0.97 & 74 & 51 & 22 \\
\hline 540 & 0.98 & 74 & 52 & 23 \\
\hline 550 & 1.00 & 75 & 52 & 23 \\
\hline 560 & 1.08 & 76 & 52 & 24 \\
\hline 570 & 1.14 & 77 & 52 & 25 \\
\hline 580 & 1.30 & 79 & 52 & 27 \\
\hline
\end{tabular}


European Journal of Sustainable Development Research, 2(2), 25

\begin{tabular}{|c|c|c|c|c|}
\hline 590 & 1.30 & 80 & 53 & 27 \\
\hline 600 & 1.39 & 82 & 54 & 28 \\
\hline 610 & 1.40 & 83 & 54 & 29 \\
\hline 620 & 1.51 & 84 & 55 & 29 \\
\hline 630 & 1.64 & 87 & 57 & 30 \\
\hline 640 & 1.68 & 90 & 58 & 31 \\
\hline 650 & 1.79 & 91 & 58 & 33 \\
\hline 660 & 1.83 & 93 & 60 & 33 \\
\hline 670 & 2.00 & 96 & 61 & 35 \\
\hline 680 & 2.05 & 99 & 63 & 37 \\
\hline 690 & 2.13 & 102 & 63 & 39 \\
\hline 700 & 2.21 & 106 & 63 & 42 \\
\hline 710 & 2.54 & 109 & 64 & 45 \\
\hline 720 & 2.41 & 110 & 65 & 46 \\
\hline 730 & 2.33 & 113 & 65 & 48 \\
\hline 740 & 2.35 & 114 & 65 & 49 \\
\hline 750 & 2.38 & 116 & 67 & 49 \\
\hline 760 & 2.77 & 119 & 70 & 49 \\
\hline 770 & 2.55 & 122 & 71 & 50 \\
\hline 780 & 2.64 & 123 & 72 & 51 \\
\hline 790 & 2.59 & 125 & 71 & 53 \\
\hline 800 & 2.61 & 126 & 70 & 55 \\
\hline 810 & 2.61 & 126 & 69 & 57 \\
\hline 820 & 2.73 & 127 & 69 & 58 \\
\hline 830 & 2.74 & 176 & 73 & 103 \\
\hline 840 & 2.68 & 128 & 67 & 61 \\
\hline 850 & 2.66 & 127 & 68 & 59 \\
\hline 860 & 2.74 & 128 & 69 & 59 \\
\hline 870 & 2.84 & 131 & 68 & 63 \\
\hline 880 & 2.98 & 134 & 66 & 67 \\
\hline 890 & 2.89 & 135 & 64 & 71 \\
\hline 900 & 3.06 & 136 & 64 & 72 \\
\hline
\end{tabular}

Table A.3. Data at ambient temperature of $32^{\circ} \mathrm{C}$ and average fuel hot-bed temperature of $1023.75^{\circ} \mathrm{C}$.

\begin{tabular}{|c|c|c|c|c|}
\hline Time (sec) & Voltage & T1 & $\mathrm{T} 2$ & T1-T2 \\
\hline 10 & 0.00 & 39 & 32 & 7 \\
\hline 20 & 0.02 & 40 & 33 & 6 \\
\hline 30 & 0.05 & 41 & 34 & 6 \\
\hline 30 & 0.20 & 43 & 34 & 8 \\
\hline 40 & 0.27 & 47 & 36 & 11 \\
\hline 50 & 0.32 & 48 & 37 & 11 \\
\hline 60 & 0.37 & 51 & 38 & 13 \\
\hline 70 & 0.39 & 55 & 45 & 10 \\
\hline 80 & 0.39 & 56 & 44 & 11 \\
\hline 90 & 0.44 & 59 & 48 & 10 \\
\hline 100 & 0.44 & 60 & 49 & 11 \\
\hline 110 & 0.46 & 60 & 48 & 12 \\
\hline 120 & 0.51 & 60 & 42 & 18 \\
\hline 130 & 0.51 & 60 & 43 & 17 \\
\hline 140 & 0.54 & 59 & 43 & 17 \\
\hline 150 & 0.54 & 60 & 43 & 17 \\
\hline 160 & 0.54 & 60 & 43 & 18 \\
\hline 170 & 0.54 & 59 & 43 & 16 \\
\hline 180 & 0.51 & 59 & 44 & 15 \\
\hline 190 & 0.46 & 57 & 43 & 15 \\
\hline 200 & 0.49 & 57 & 44 & 13 \\
\hline 210 & 0.49 & 57 & 44 & 13 \\
\hline 220 & 0.49 & 58 & 45 & 13 \\
\hline 230 & 0.51 & 60 & 47 & 13 \\
\hline 240 & 0.54 & 61 & 46 & 15 \\
\hline 250 & 0.59 & 65 & 49 & 16 \\
\hline 260 & 0.66 & 74 & 57 & 16 \\
\hline 270 & 0.73 & 76 & 57 & 20 \\
\hline 280 & 0.81 & 78 & 58 & 20 \\
\hline 290 & 0.93 & 79 & 58 & 21 \\
\hline 300 & 0.88 & 78 & 57 & 21 \\
\hline 310 & 1.03 & 78 & 56 & 22 \\
\hline 320 & 0.98 & 80 & 59 & 21 \\
\hline
\end{tabular}


Ajah / Performance Evaluation of Thermoelectric Charcoal Stove

\begin{tabular}{|c|c|c|c|c|}
\hline 330 & 0.98 & 80 & 58 & 22 \\
\hline 340 & 1.00 & 79 & 56 & 23 \\
\hline 350 & 1.00 & 80 & 57 & 23 \\
\hline 360 & 1.03 & 80 & 58 & 23 \\
\hline 370 & 1.03 & 80 & 58 & 22 \\
\hline 380 & 1.08 & 80 & 58 & 23 \\
\hline 390 & 1.08 & 80 & 57 & 23 \\
\hline 400 & 1.17 & 79 & 57 & 23 \\
\hline 410 & 1.08 & 80 & 56 & 24 \\
\hline 420 & 1.10 & 80 & 57 & 23 \\
\hline 430 & 1.10 & 81 & 57 & 24 \\
\hline 440 & 1.12 & 81 & 58 & 23 \\
\hline 450 & 1.12 & 81 & 57 & 23 \\
\hline 460 & 1.15 & 80 & 58 & 23 \\
\hline 470 & 1.15 & 81 & 57 & 24 \\
\hline 480 & 1.15 & 81 & 57 & 24 \\
\hline 490 & 1.17 & 80 & 57 & 24 \\
\hline 500 & 1.27 & 81 & 56 & 25 \\
\hline 510 & 1.20 & 80 & 55 & 25 \\
\hline 520 & 1.22 & 80 & 54 & 26 \\
\hline 530 & 1.22 & 80 & 53 & 27 \\
\hline 540 & 1.22 & 80 & 54 & 27 \\
\hline 550 & 1.27 & 80 & 54 & 27 \\
\hline 560 & 1.30 & 80 & 52 & 28 \\
\hline 570 & 1.27 & 81 & 52 & 29 \\
\hline 580 & 1.34 & 81 & 51 & 29 \\
\hline 590 & 1.32 & 81 & 52 & 29 \\
\hline 600 & 1.32 & 81 & 52 & 29 \\
\hline 610 & 1.32 & 80 & 52 & 28 \\
\hline 620 & 1.37 & 80 & 53 & 28 \\
\hline 630 & 1.52 & 82 & 54 & 29 \\
\hline 640 & 1.44 & 83 & 54 & 29 \\
\hline 650 & 1.52 & 83 & 54 & 28 \\
\hline 660 & 1.56 & 83 & 56 & 27 \\
\hline 670 & 1.76 & 86 & 58 & 29 \\
\hline 680 & 1.91 & 90 & 60 & 29 \\
\hline 690 & 2.05 & 93 & 62 & 32 \\
\hline 700 & 2.15 & 97 & 61 & 36 \\
\hline 710 & 2.42 & 101 & 61 & 40 \\
\hline 720 & 2.49 & 103 & 60 & 43 \\
\hline 730 & 2.32 & 106 & 60 & 46 \\
\hline 740 & 2.32 & 106 & 59 & 47 \\
\hline 750 & 2.32 & 106 & 60 & 46 \\
\hline 760 & 2.64 & 107 & 61 & 46 \\
\hline 770 & 2.52 & 109 & 61 & 48 \\
\hline 780 & 2.64 & 110 & 61 & 50 \\
\hline 790 & 2.49 & 112 & 60 & 52 \\
\hline 800 & 2.59 & 113 & 59 & 55 \\
\hline 810 & 2.66 & 115 & 57 & 58 \\
\hline 820 & 2.83 & 116 & 55 & 62 \\
\hline 830 & 2.98 & 118 & 54 & 64 \\
\hline 840 & 2.98 & 119 & 52 & 67 \\
\hline 850 & 2.91 & 117 & 56 & 62 \\
\hline 860 & 3.10 & 121 & 60 & 61 \\
\hline 870 & 3.23 & 128 & 59 & 69 \\
\hline 880 & 3.30 & 136 & 59 & 77 \\
\hline 890 & 3.45 & 140 & 55 & 85 \\
\hline 900 & 3.49 & 141 & 55 & 86 \\
\hline
\end{tabular}

Table A.4. Data at ambient temperature of $30^{\circ} \mathrm{C}$ and average fuel hot-bed temperature of $1023.75^{\circ} \mathrm{C}$.

\begin{tabular}{ccccc}
\hline Time (sec) & Voltage & T1 & T2 & T1-T2 \\
\hline 10 & 0.00 & 42 & 30 & 38 \\
\hline 20 & 0.00 & 43 & 39 & 38 \\
\hline 30 & 0.03 & 43 & 4 & 38 \\
\hline 30 & 0.10 & 45 & 47 & 40 \\
\hline 40 & 0.16 & 49 & 9 \\
\hline 50 & 0.20 & 50 & 42 \\
\hline
\end{tabular}


European Journal of Sustainable Development Research, 2(2), 25

\begin{tabular}{|c|c|c|c|c|}
\hline 70 & 0.27 & 52 & 45 & 7 \\
\hline 80 & 0.26 & 53 & 44 & 8 \\
\hline 90 & 0.30 & 55 & 47 & 8 \\
\hline 100 & 0.31 & 56 & 48 & 8 \\
\hline 110 & 0.34 & 57 & 48 & 9 \\
\hline 120 & 0.39 & 58 & 46 & 12 \\
\hline 130 & 0.43 & 59 & 47 & 12 \\
\hline 140 & 0.48 & 60 & 49 & 11 \\
\hline 150 & 0.49 & 61 & 49 & 12 \\
\hline 160 & 0.60 & 63 & 48 & 14 \\
\hline 170 & 0.58 & 62 & 48 & 14 \\
\hline 180 & 0.60 & 63 & 48 & 15 \\
\hline 190 & 0.59 & 62 & 47 & 15 \\
\hline 200 & 0.62 & 63 & 48 & 15 \\
\hline 210 & 0.62 & 63 & 48 & 15 \\
\hline 220 & 0.63 & 64 & 48 & 16 \\
\hline 230 & 0.64 & 65 & 49 & 16 \\
\hline 240 & 0.67 & 67 & 50 & 17 \\
\hline 250 & 0.74 & 70 & 52 & 18 \\
\hline 260 & 0.87 & 77 & 57 & 20 \\
\hline 270 & 0.91 & 79 & 57 & 21 \\
\hline 280 & 0.96 & 79 & 58 & 21 \\
\hline 290 & 1.04 & 80 & 58 & 22 \\
\hline 300 & 1.01 & 79 & 57 & 22 \\
\hline 310 & 1.12 & 79 & 55 & 24 \\
\hline 320 & 1.09 & 80 & 56 & 24 \\
\hline 330 & 1.17 & 80 & 56 & 24 \\
\hline 340 & 1.14 & 80 & 54 & 25 \\
\hline 350 & 1.13 & 80 & 55 & 25 \\
\hline 360 & 1.30 & 81 & 56 & 25 \\
\hline 370 & 1.23 & 82 & 56 & 26 \\
\hline 380 & 1.38 & 83 & 57 & 26 \\
\hline 390 & 1.44 & 83 & 57 & 26 \\
\hline 400 & 1.65 & 85 & 58 & 26 \\
\hline 410 & 1.86 & 88 & 57 & 31 \\
\hline 420 & 1.87 & 88 & 57 & 31 \\
\hline 430 & 1.89 & 89 & 58 & 31 \\
\hline 440 & 1.92 & 89 & 58 & 31 \\
\hline 450 & 1.93 & 89 & 58 & 31 \\
\hline 460 & 2.02 & 89 & 59 & 30 \\
\hline 470 & 2.01 & 89 & 59 & 31 \\
\hline 480 & 1.97 & 90 & 58 & 31 \\
\hline 490 & 2.01 & 90 & 58 & 31 \\
\hline 500 & 2.15 & 91 & 59 & 32 \\
\hline 510 & 2.25 & 91 & 58 & 33 \\
\hline 520 & 2.14 & 91 & 58 & 33 \\
\hline 530 & 2.30 & 92 & 58 & 34 \\
\hline 540 & 2.31 & 94 & 59 & 35 \\
\hline 550 & 2.55 & 94 & 59 & 36 \\
\hline 560 & 2.33 & 94 & 58 & 36 \\
\hline 570 & 2.56 & 95 & 58 & 36 \\
\hline 580 & 2.35 & 95 & 58 & 37 \\
\hline 590 & 2.46 & 97 & 58 & 39 \\
\hline 600 & 2.50 & 106 & 55 & 51 \\
\hline 610 & 2.66 & 106 & 55 & 51 \\
\hline 620 & 2.69 & 106 & 55 & 51 \\
\hline 630 & 2.76 & 107 & 55 & 52 \\
\hline 640 & 2.74 & 108 & 56 & 53 \\
\hline 650 & 2.71 & 113 & 55 & 58 \\
\hline 660 & 2.86 & 113 & 56 & 57 \\
\hline 670 & 3.10 & 115 & 57 & 58 \\
\hline 680 & 3.15 & 120 & 59 & 61 \\
\hline 690 & 3.19 & 122 & 59 & 63 \\
\hline
\end{tabular}


Ajah / Performance Evaluation of Thermoelectric Charcoal Stove

\begin{tabular}{lllll}
\hline 700 & 3.08 & 125 & 60 & 65 \\
\hline 710 & 3.60 & 127 & 60 & 67 \\
\hline 720 & 3.50 & 128 & 59 & 69 \\
\hline 730 & 3.40 & 130 & 59 & 70 \\
\hline 740 & 3.77 & 130 & 58 & 71 \\
\hline 750 & 3.46 & 131 & 59 & 72 \\
\hline 760 & 3.71 & 132 & 59 & 74 \\
\hline 770 & 3.61 & 133 & 59 & 74 \\
\hline 780 & 3.66 & 134 & 59 & 76 \\
\hline 790 & 3.61 & 59 & 78 \\
\hline 800 & 3.63 & 58 & 82 \\
\hline 810 & 3.71 & 136 & 58 & 82 \\
\hline 820 & 3.80 & 137 & 56 & 84 \\
\hline 830 & 3.87 & 138 & 56 & 82 \\
\hline 840 & 3.98 & 138 & 55 & 83 \\
\hline 850 & 3.85 & 139 & 57 & 88 \\
\hline 860 & 3.75 & 139 & 59 & 91 \\
\hline 870 & 3.98 & 142 & 58 & 91 \\
\hline 890 & 4.04 & 146 & 58 & 89 \\
\hline 900 & 4.23 & 150 & 61 & \\
\hline
\end{tabular}

Table A.5. Data at ambient temperature of $29^{\circ} \mathrm{C}$ and average fuel hot-bed temperature of $1023.75^{\circ} \mathrm{C}$.

\begin{tabular}{|c|c|c|c|c|}
\hline Time (sec) & Voltage & T1 & $\mathrm{T} 2$ & T1-T2 \\
\hline 10 & 0.00 & 45 & 29 & 3 \\
\hline 20 & 0.00 & 46 & 43 & 4 \\
\hline 30 & 0.02 & 46 & 43 & 3 \\
\hline 30 & 0.02 & 47 & 42 & 6 \\
\hline 40 & 0.07 & 48 & 41 & 7 \\
\hline 50 & 0.10 & 49 & 42 & 8 \\
\hline 60 & 0.15 & 49 & 45 & 4 \\
\hline 70 & 0.17 & 50 & 45 & 5 \\
\hline 80 & 0.15 & 50 & 44 & 6 \\
\hline 90 & 0.17 & 51 & 45 & 6 \\
\hline 100 & 0.20 & 52 & 46 & 6 \\
\hline 110 & 0.24 & 54 & 49 & 6 \\
\hline 120 & 0.29 & 56 & 50 & 6 \\
\hline 130 & 0.37 & 58 & 52 & 7 \\
\hline 140 & 0.44 & 61 & 55 & 6 \\
\hline 150 & 0.46 & 62 & 55 & 7 \\
\hline 160 & 0.68 & 65 & 54 & 11 \\
\hline 170 & 0.68 & 65 & 54 & 11 \\
\hline 180 & 0.64 & 66 & 53 & 13 \\
\hline 190 & 0.71 & 67 & 52 & 15 \\
\hline 200 & 0.73 & 68 & 52 & 16 \\
\hline 210 & 0.76 & 69 & 52 & 17 \\
\hline 220 & 0.78 & 70 & 51 & 19 \\
\hline 230 & 0.78 & 71 & 52 & 19 \\
\hline 240 & 0.81 & 74 & 54 & 20 \\
\hline 250 & 0.90 & 74 & 54 & 20 \\
\hline 260 & 1.10 & 81 & 58 & 23 \\
\hline 270 & 1.10 & 81 & 58 & 23 \\
\hline 280 & 1.12 & 81 & 58 & 23 \\
\hline 290 & 1.17 & 81 & 57 & 24 \\
\hline 300 & 1.15 & 81 & 58 & 23 \\
\hline 310 & 1.22 & 80 & 54 & 26 \\
\hline 320 & 1.22 & 81 & 54 & 27 \\
\hline 330 & 1.37 & 80 & 54 & 27 \\
\hline 340 & 1.30 & 81 & 53 & 28 \\
\hline 350 & 1.27 & 81 & 53 & 28 \\
\hline 360 & 1.59 & 82 & 54 & 28 \\
\hline 370 & 1.44 & 83 & 54 & 29 \\
\hline 380 & 1.69 & 85 & 56 & 29 \\
\hline 390 & 1.81 & 85 & 57 & 29 \\
\hline 400 & 2.15 & 91 & 60 & 31 \\
\hline 410 & 2.66 & 96 & 57 & 39 \\
\hline 420 & 2.66 & 97 & 58 & 39 \\
\hline
\end{tabular}


European Journal of Sustainable Development Research, 2(2), 25

\begin{tabular}{|c|c|c|c|c|}
\hline 430 & 2.69 & 97 & 59 & 38 \\
\hline 440 & 2.74 & 97 & 58 & 39 \\
\hline 450 & 2.76 & 98 & 59 & 39 \\
\hline 460 & 2.91 & 98 & 60 & 38 \\
\hline 470 & 2.88 & 98 & 60 & 38 \\
\hline 480 & 2.81 & 98 & 60 & 38 \\
\hline 490 & 2.86 & 99 & 60 & 39 \\
\hline 500 & 3.05 & 102 & 62 & 40 \\
\hline 510 & 3.32 & 102 & 61 & 41 \\
\hline 520 & 3.08 & 102 & 63 & 40 \\
\hline 530 & 3.40 & 103 & 63 & 41 \\
\hline 540 & 3.42 & 108 & 64 & 44 \\
\hline 550 & 3.84 & 108 & 64 & 45 \\
\hline 560 & 3.37 & 107 & 64 & 44 \\
\hline 570 & 3.86 & 108 & 64 & 44 \\
\hline 580 & 3.37 & 109 & 64 & 45 \\
\hline 590 & 3.62 & 114 & 64 & 50 \\
\hline 600 & 3.69 & 131 & 57 & 74 \\
\hline 610 & 4.01 & 131 & 57 & 74 \\
\hline 620 & 4.03 & 132 & 58 & 75 \\
\hline 630 & 4.01 & 133 & 57 & 76 \\
\hline 640 & 4.06 & 133 & 57 & 76 \\
\hline 650 & 3.91 & 144 & 56 & 88 \\
\hline 660 & 4.18 & 144 & 56 & 88 \\
\hline 670 & 4.45 & 145 & 56 & 88 \\
\hline 680 & 4.40 & 151 & 58 & 93 \\
\hline 690 & 4.35 & 151 & 57 & 94 \\
\hline 700 & 4.03 & 153 & 58 & 95 \\
\hline 710 & 4.79 & 153 & 59 & 94 \\
\hline 720 & 4.52 & 153 & 58 & 95 \\
\hline 730 & 4.50 & 154 & 58 & 95 \\
\hline 740 & 5.23 & 154 & 58 & 96 \\
\hline 750 & 4.62 & 157 & 59 & 98 \\
\hline 760 & 4.79 & 157 & 58 & 99 \\
\hline 770 & 4.72 & 158 & 58 & 100 \\
\hline 780 & 4.69 & 158 & 58 & 100 \\
\hline 790 & 4.74 & 158 & 58 & 100 \\
\hline 800 & 4.69 & 159 & 58 & 101 \\
\hline 810 & 4.77 & 159 & 58 & 101 \\
\hline 820 & 4.79 & 159 & 57 & 102 \\
\hline 830 & 4.77 & 158 & 58 & 100 \\
\hline 840 & 4.99 & 160 & 58 & 102 \\
\hline 850 & 4.81 & 160 & 58 & 103 \\
\hline 860 & 4.42 & 163 & 58 & 105 \\
\hline 870 & 4.74 & 163 & 57 & 106 \\
\hline 880 & 4.79 & 164 & 58 & 106 \\
\hline 890 & 5.03 & 163 & 66 & 97 \\
\hline 900 & 5.25 & 159 & 67 & 92 \\
\hline
\end{tabular}

